\title{
Tuan Tanah dan Lurah : Relasi Politik Lokal Patron-Client di Desa Sukorejo Kecamatan Godanglegi Kabupaten Malang dalam Kurun Waktu 2007-2013
}

\author{
Annise Sri Maftuchin \\ Antropologi - FIB Universitas Brawijaya \\ annimaftuchin@gmail.com
}

\begin{abstract}
This article discusses the local politic in Sukorejo Gondanglegi Malang by focusing on the Lurah second round election. This study applied ethnographic methods to explore the strategy applied by the elected Lurah in order to ensure he is elected for the second round. The study found that the elected Lurah continuously search for support from his voters in order to ensure that the voters support him to win the election for the second round. In an election, the elected Lurah needs Rp. 300 million to fund his voters, while the salary he received as Lurah is only Rp.1.500.000- Rp.2.000.000 monthly, plus crop from a three hectares land allocated to Lurah. Election fund might create financial burden for the elected Lurah and limited financial resources lead to failure in the second round election. However, elected Lurah can minimize the failure using patron-client strategy. This strategy enables him build a political reciprocity between him and his voters which will benefit him in the election, to win his position for the second time.
\end{abstract}

Keywords: Patron-Client, Politics Village, Reciprocity, Subsistence, Landlord

\begin{abstract}
Abstrak
Artikel ini membahas model politik lokal di Sukorejo Gondanglegi Malang dengan berfokus pada pemilihan Lurah yang kedua. Penelitian ini menerapkan metode etnografi untuk memaparkan strategi yang diterapkan oleh Lurah terpilih untuk memastikan ia terpilih kembali pada pemilihan kedua. Penelitian ini menemukan bahwa Lurah terpilih terus mencari dukungan dari pemilih dalam rangka memastikan bahwa pemilih mendukung dia untuk memenangkan pemilu yang kedua. Dalam pemilihan, calon lurah membutuhkan Rp. 300 juta untuk mendanai pemilih, sementara gaji yang dia terima sebagai Lurah hanya Rp.1.500.000- Rp.2.000.000 bulanan, ditambah tanah bengkok seluas tiga hektar. Dana pencalonan yang cukup besar dapat menjadi permasalahan keuangan untuk calon lurah yang mengalami kekalahan. Namun, kerugian akibat kegagalan pemilihan Lurah dapat diminimalisir menggunakan strategi patron-klien. Strategi ini memungkinkan calon lurah membangun hubungan timbal balik antara dirinya dan pemilih sebelumnya, sehingga dapat menguntungkan dirinya sebagai pemenang dalam pemilihan yang kedua.
\end{abstract}

Kata Kunci : Patron-Klien, Politik Desa, Resiprositas, Subsisten, Tuan Tanah

\section{Pendahuluan}

Ranah lokal pedesaan Jawa selalu lekat kaitannya dangan pertanian subsisten. Kesuburan tanah dan pola irigasi yang dekat dengan sumber air menempatkan sawah sebagai aset utama. Tidak hanya menyokong perekonomian penduduk, sawah juga menjadi bagian utama dalam regulasi pemerintahan desa. Seorang lurah atau kepada desa memiliki hak atas kelola sawah desa dan upah bulanan yang diberikan pemerintah pusat. Fenomena ini terlihat jelas pada pola politik lokal dan 
budaya keseharian masyarakat Desa Sukorejo Gondanglegi Kabupaten Malang.

Desa Sukorejo merupakan desa yang berada di Kecamatan Gondanglegi. Desa ini memiliki wilayah pertanian yang sangat luas dibanding desa lainnya. Dari data morfologi penduduk dijelaskan luas area pertanian yang terdiri dari 125 hektar persawahan padi; 1,5 hektar kebun sayuran; 2 hektar kebun buah-buahan;15 hektar kebun tebu dan 15,028 hektar tanah kas atau bengkok desa. Rincian luas tanah tersebut mempengaruhi produktivitas pangan di Kecamatan Gondanglegi. Selain itu, keberadaan tanah khas desa atau yang dinamai tanah "bengkok" desa menjadi pertanda masih aktifnya pola pemerintahan dengan tata cara lokal di sana.

Pembahasan mengenai perpolitikan lokal di daerah pedasaan sebelumnya telah juga di bahas oleh Rohmawati (2005) dan Halili (2009). Tulisan Rohmawati menjelaskan tipikal politik desa yang ada di Desa Masin masih menggunakan money politik dimana sokongan suara secara langsung dibeli lewat uang. Semakin banyak dana yang dikeluarkan akan semakin banyak dukungan yang didapatkan. Hal yang sama juga dijelaskan oleh Halili (2009) dalam praktek uang yang dilakukan oleh masyarakat Madura. Praktek-praktek politik lokal di pedesaan memang lebih dekat dengan pola money politik, namun tidak hanya pola politik yang mempengaruhi relasi politik elit desa. Dalam pola politik Desa Sukorejo, relasi sosial politik lebih menekankan pada kaitan budaya pertanian.

Kajian tetang budaya petani yang dijelaskan oleh Scott (1981) memetakan relasi antara tuan tanah dan petani kecil dalam ikatan relasi 'patron-klien'. Hal tersebut didasarkan atas prinsip-prinsip resiprositas dan subsistensi yang berpangkal dari kekuasaan di dalam masyarakat. Resiprositas adalah hubungan saling menguntungkan yang terikat dalam konsep pemberian (Mauss, 2002), dimana pemilik tanah memberi upah pada pekerjanya setara dan seringkali lebih dengan apa yang dikerjakan oleh mereka. Konsep pemberian (Mauss, 2002) lebih mengacu sebagai landasan bagi stuktur persekutuan dan persahaban yang kurang lebih menggambarkan harmonisasi masyarakat tradisional. Pola pemberian ini kemudian mengacu pada konsep subsisten, dimana hak atas pekerja tidak hanya diberikan lewat upah saja dan ini digunakan sebagai titik putus ledakan kemarahan (Scott, 1981). Akan tetapi, para buruh pada suatu saat memiliki kewajiban moral yang harus dikembalikan dari resiprositas yang bersifat subsisten mereka kepada pemilik tanah atau pemilik modal. Pola tersebut digambarkan secara langsung dalam relasi politik desa Sukorejo.

Gambaran dasar yang terlihat dari pola resiprositas dan subsistensi yang menciptakan hubungan 'patron-klien' dapat terlihat dari keberadaan tanah bengkok atau tanah khas desa. Tanah bengkok atau tanah khas desa merupakan tanah hak guna yang diberikan kepada aparatur atau pamong desa sebagai upah pengganti gaji (Tauchid, 2009:144). Struktur administrasi yang demikian memaksa setiap apratur desa masuk dalam pelaku prinsip-prinsip resiprositas dan subsisten. Terlebih dalam relasi antara buruh tani dan aparatur atau pamong desa. Di beberapa desa pola patronklien juga diwujudkan dalam prinsip sewa menyewa lahan bengkok. Praktek tersebut melibatkan aparatur desa sebagai pemegang hak kelola dengan para petani penyewa lahan. Di desa Sukorejo sendiri prinsip resiprositas sebenarnya diwujudkan lewat relasi buruh dan petani. Dari prinsip tersebut setiap juragan tanah memiliki banyak pegawai dan tentunya memperkuat kedudukan dan pola kuasa juragan tersebut di Desa Sukorejo. Keunikan inilah yang melatarbelakangi pola perpolikan di Desa Sukorejo.

Titik permasalahan ditonjolkan untuk melihat korelasi politik desa yang didasarkan atas prinsip resiprositas dan 
subsisten dapat dilihat lewat peraturan penggunaan tanah bengkok dalam UU No.5. Tanah bengkok dalam UndangUndang Nomor 5 Tahun 1960 telah diatur dalam Ketentuan-Ketentuan Konversi pada Pasal VI menjadi Hak Pakai yaitu:

Hak-hak atas tanah yang memberi wewenang sebagaimana atau mirip dengan hak yang dimaksud dalam Pasal 41 ayat 1 seperti yang disebut dengan nama sebagai di bawah, yang ada pada mulai berlakunya Undang-Undang ini, yaitu: hak vruchtgebruik, gebruik, grant controleur, bruikleen, ganggam bauntuik, anggaduh,bengkok, lungguh, pituwas, dan hak-hak lain dengan nama apapun juga yang akan ditegaskan lebih lanjut oleh Menteri Agraria, sejak mulai berlakunya Undang-Undang ini menjadi hak pakai tersebut dalam Pasal 41 ayat 1 , yang memberi wewenang dan kewajiban sebagaimana yang dipunyai oleh pemegang haknya pada mulai berlakunya Undang-Undang ini, sepanjang tidak bertentangan dengan jiwa dan ketentuan-ketentuan UndangUndang ini. ${ }^{1}$

Pemakaian hak guna lahan yang digunakan oleh aparatur desa memiliki wewenang yang utuh dan dilindungi oleh Negara. Persoalan yang dipertanyakan adalah mengenai bagaimana korelasi antara hak guna tanah dengan perpolitikan desa yang dijalankan oleh Lurah Abdi pada pemilihannya yang ke-2 tahun 2007. Hal ini memungkinkan terbentuknya relasi patronklien baru antara penguasa desa dan lurahnya. Terlebih hubungan pemakaian hak guna lahan bengkok digunakan menyalahi aturan jabatan yang telah berakhir. Kejadian ini memperlihatkan bahwa posisi lurah memiliki kelas prestis yang cukup tinggi mengingat luas tanah

\footnotetext{
${ }^{1}$ Lihat di Tobing, A. A. (2009). Eksistensi Tanah Bengkok Setelah Perubahannya Pemerintahan Desa
}

bengkok desa untuk lurah adalah 3 Hektar dari 15,058 Hektar tanah kas desa.

\section{Kerangka Konsep dan Metode Penelitian}

Penelitian ini menggunakan metode penelitian etnografi, dimana pengamatan dan wawancara (open interview and indepth interview) dilakukan dengan melakukan kontak langsung dengan masyarakat Sukorejo. Metode ini menuntut peneliti untuk tinggal dan membaur dengan masyarakat layaknya anggota masyarakat itu sendiri. Hal tersebut berfungsi dalam mendengarkan dan merespon data yang dipaparkan oleh masyarakat secara maksimal. Pola ini merupakan bentuk penggalian informasi dari native's point of views yang merupakan komponen utama (Fettersman, 2010; Simatupang, 2013:9394). Diperkuat dengan data sekunder yang diperoleh melalui studi literatur berupa ebook, Jurnal dan buku penunjang sehingga dapat memperkuat gambaran politik desa Sukorejo yang sedang dijalankan. Sedangkan analisis data menggunakan model Miles dan Huberman yang mengemukakan bahwa aktivitas dalam analisis data kualitatif dilakukan secara interaktif dan berlangsung secara terusmenerus sampai tuntas hingga data sudah jenuh. Akitivitas analisis data ini meliputi data reduction, display data, dan conclucion drawing (Sugiyono, 2012: 232).

Penelitian ini dianalisis dengan menggunakan konsep patron-klien Scott (1981) dan teori Galtung yang mengemukakan bahwa "power deriving from something one is, power deriving from something one has and something power deviring from posisition from structure" sebuah kekuasaan dapat diperoleh jika memang kekuasaan itu mutlak ada, kekuasan juga dapat di peroleh dengan sebuah kekayaan dan kekuasaan diperoleh

Menjadi Kelurahan di Kota Salatiga. Semarang: Universitas Diponegoro. HIm. 37 
karena adanya posisi struktural (Anshoriy, 2008, hlm 15).

Konsep 'patron-klien' sebenarnya menempatkan Lurah Abdi sebagai Klien dari seorang Juragan Tanah yang memiliki depo penggilingan padi di sana. Patron klien ini memanfaatkan akses suara dimana kekayaan dan kekuasaan melatarbelakangi hubungan resiprositas antara mereka. Scott (1981) menjelaskan bahwa relasi PatronKlien memiliki ikatan yang cukup kuat untuk hak-hak dan kewajiban timbal balik, yang memberi kekuatan sosial kepada ikatan-ikatan tertentu. Hal inilah yang tergambar dalam pola perpolitikan lurah Abdi di Desa Sukorejo Godanglegi Kabupaten Malang.

\section{Pemilu Lokal 2007}

Lurah Abdi merupakan keturunan Pendalungan yang berasal dari Probolinggo dan menetap di Sukorejo mengikuti sang istri. Istri Pak Abdi merupakan penduduk asli Sukorejo, hal tersebut dipaparkan oleh Pak Sholikin (44 th). Pak Sholikin menjelaskan "Abdi iku duduk wong kene tapi wong Pendalungan sing asli kene kui bojone" Abdi itu bukan penduduk sini melainkan orang Pendalungan yang asli sini itu Istrinya (Wawancara, 26 Juni 2013). Lurah Abdi menjabat selama dua periode sejak 2005 menggantikan lurah yang saat itu terlibat kasus 'Tukar Guling'?

Saat menjabat menggantikan Pak Purdopo, Pak Abdi lebih konsisten membawa ritme perpolitikannya pada model perpolitikan Islam. Sejak mulai menjabat tahun 2000, dia berambisi untuk mengaktifkan kembali kegiatan- kegiatan Islamiah lewat beberapa organisasi yang dibentuknya. Salah satu organisasi tersebut adalah Resco (Remaja Sukorejo), organisasi tersebut mulai

2 Kasus 'Tukar Guling' merupakan kasus yang dilakukan oleh Lurah Purdopo dalam kasus tersebut terjadi kesalah pahaman antara lurah dan rakyatnya. Permasalahan yang terjadi saat itu adalah penukaran tanah bengkok dengan tanah milik warga untuk berkiprah dibeberapa sektor dari mulai kegiatan Dhiba'an ${ }^{3}$ hingga pengajian Istighosah. Tak hanya itu sistem pemerintahan tanpa pungutan memangang mejadi misi utamanya. Hal ini dijelaskan oleh Pak Ramin (62 th) sebagai berikut :

"Abdi iku wonge apik soale gak enek pungutan blasi i lak arep ngurus opoopo. lak yalone neh yo mesti akeh sing milih, tapi iki wez terakhir dadi yo embuh sopo gantine" (Wawancara, 26 Juni 2013)

Abdi itu orangnya baik soalnya ndak ada pungutan kalau misalnya mau ngurus kepentingan apa-apa. Kalau nyalonkan lagi pasti banyak yang memilih, tapi ini sudah masa jabatannya yang terakhir jadi ya ndak tahu siapa gantinya.

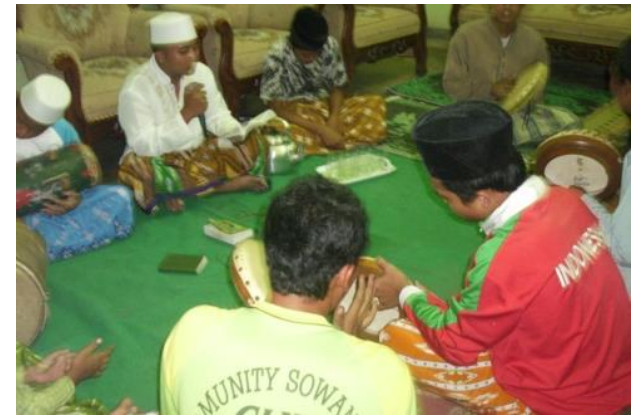

Aktifitas Tiba'an Resco (Sumber : Dokumen Pribadi)

Pola pemerintahan yang berbasis Islam mendapat dukungan dari sebagian penduduk Sukorejo dan mendapat kecaman bagi sebagian penduduk yang kontra terhadap lurah Abdi. Keberadaan kelompok kontra sebenarnya didasari akibat minimnya eksistensi kebudayaan Jawa bagi mereka yang tidak bukan merupakan anggota kaum fanatik Islam. Akan tetapi, bagi mereka yang kontra mereka harus memilih Lurah Abdi dalam pemilu lokal 2007. Hal tersebut dikarenakan adanya prinsip resiprositas dan subsitensi yang berjalan disana. Keberadaan juragan yang

pembangunan sekolah SMP. Dari sini elektabilitas Pak Purdopo sebagai lurah secara drastis menurun hingga dilengserkan dari jabatan lurah dan digantikan oleh Pak Abdi.

3 Dhiba'an adalah shalawat yang dilagukan dan diiringi dengan suara rebana 
tidak sebanding dengan buruh membuat penguasaan suara untuk pemilihan lurah Abdi sangat terlihat kuat. Fakta ini didukung oleh penjelasan Pak Widiaji (38 th) yang menerangkan:

\section{"Disini itu perbandingan juragan dan buruh itu tidak sebanding. Buruh e luweh akeh timbang juragane. Orang-orang disini itu lebih memilih aspirasi juragan dari pada memilih aspirasi sendiri karena ketakutan kalau nanti di pecat lha mau makan apa, Mbak..."(wawancara, 27 Juni 2013).}

Kepemimpinan Lurah Abdi yang didapat dari menggatikan posisi Pak Purdopo kemudian mulai berakhir pada 2007. Saat itu perebutan posisi lurah ditempatkan sebagai satu proses inisiasi yang sangat prestise bagi masyarakat Desa Sukorejo. Mereka yang dianggap Juragan saling mencalonkan diri menjadi lurah. Fenomena pencalonan jabatan ini sebenarnya dilatarbelakangi oleh penguasaan hak guna pakai tanah bengkok selebar 3 Hektar untuk jabatan Lurah. Fakta ini diceritakan langsung oleh Pak Misran (64 th) yang menerangkan:

"Nek kene ki memang kesubure ora enek seng ngalahne, sumbere akeh desone makmur. Mangkane nek kene bengkok kanggo perangkat deso ombo- ombo ,disek iki lak miturut ceritane onok wong tuek jluk ngombe nek kulon kali ra di wenehi ning etan kali di wenehi ngombe dadi lan sedane mbah-mbah kui mau. Ceritane ngunu mangkane nek kene ki pangkat lurah kui digawe rebutan lawong tanah bengkok e wae ambane ra enek sing ngalahne 3 hektar" (wawancara, 28 Juni 2013).

\footnotetext{
${ }^{4}$ Menurut keterangan warga tuan tanah tersebut merupakan anak dari Kaji Aziz. Sosok Kaji Azis sendiri merupakan tuan tanah yang memiliki tanah terluas di Desa Sukorejo pada Masa itu. Kaji Azis sendiri awalnya Menjabat menjadi lurah, namun masa jabatannya tak lebih dari satu tahun. Hal
}

Disini memang tanahnya subur tak terkalahkan, sumber airnya banyak desanya makmur. Mangkanya disini tanah bengkok bagi perangkat desa luas-luas, dulu menurut sejarahnya ada orang tua minta minum di barat sungai tapi ndak di kasih, dikasihnya justru di daerah timur sungai jadilah doa dari nenek-nenek itu. ceritanya gitu mangkannya disini pangkat lurah itu jadi rebutan, karena tanah bengkoknya saja luasnya ndak ada yang lenih 4 hektar, disini 3 hektar.

Motif hak tanah bengkok inilah yang kemudian menggiurkan Lurah Abdi untuk mencalonkan diri kembali pada 2007. Saat itu Calon yang diusung adalah Pak Abdi, Pak Purdopo dan Pak Widiaji. Dari tiga tersebut dua diantaranya merupakan calon terkuat karena mengeluarkan dana kampaye secara besar-besaran. Pak Abdi saat itu memilih menggunakan sokongan dukungan dari komunitas Islamnya. Tindakan tersebut semata-mata ditujukan untuk memperoleh dukungan para kantong-kantong suara yang mayoritas berasal dari tuan tanah.

\section{Tuan Tanah dengan Calon Lurah}

Praktek politik yang dijalankan Lurah Abdi selama masa pergantian jabatan adalah menjalin relasi dengan tuan tanah yang ada di Desa Sukorejo. Sebelumnya ikatan ini belum pernah dilakukan bahkan Lurah Abdi baru mengenal sosok tuan tanah di desa tempat tinggalnya selama dia menjabat sabagai Lurah pada periode pertama. Sosok tuan tanah tersebut sebenarnya sudah tidak asing bagi masyarakat Desa Sukorejo. Hal ini dikarenakan ayah dari tuan tanah ini dulunya merupakan Lurah Desa Sukorejo ${ }^{4}$.

tersebut terjadi karena Kaji Azis saat itu terlibat penggelapan ribuan pupuk BIMAS. Kasus penggelapan tersebut dilakukan oleh teman Kaji Azis dibawah nama Kaji Azis. Dari kejadian tersebut Kaji Azis melarang keturunannya menjadi lurah di Desa Sukorejo. 
Nama Kaji Zen disebut-sebut menggantikan ayahnya Kaji Aziz menjadi tuan tanah di daerah Desa Sukorejo. Kepemilikan tanah yang cukup luas ditambah dengan gudang beras serta depo penggilingan padi membuat Kaji Zen menjadi tumpuan perekonomian bagi sebagian besar masyarakat Desa Sukorejo. Hampir $50 \%$ dari masyarakat Sukorejo berprofesi sebagai buruh tani dan pekerja di gudang beras dan sawah Kaji Zen ${ }^{5}$. Selain itu, Kaji Zen juga sangat disegani oleh masyarakat Desa Sukorejo, hal ini karena sifat kedermawanan Kaji Zen kepada warga. Sentralisasi perekonomian masyarakat Sukorejo sebenarnya tidak hanya terfokus pada ranah pertanian. Akan tetapi, mayoritas tingkat perekonomian masyarakatnya ada pada tingkat menengah ke bawah. Sehingga, hal ini mempengaruhi pada pola pekerjaan yang dijalankan dibawah tuan tanah dan juga pemilik kapital selain tuan tanah.

Pola patron-klien yang dibangun oleh Kaji Zen memposisikan menekankan ide moral dan resiprositas, hak-hak dan kewajiban timbal balik ${ }^{6}$. Tentunya barang dan jasa yang dipertukarkan bersifat tidak sama. Contoh paling nyata adalah Kaji Zen memiliki banyak buruh maka buruh Kaji Zen memiliki tingkat kepatuhan yang tinggi terhadap Kaji Zen sebagai Patronnya. Peluang inilah yang kemudian didekati oleh Lurah Abdi sebagai calon lumbung suara bagi pencalonannya yang kedua. Pak Sami'i yang merupakan sopir Kaji Zen menjelaskan:

\footnotetext{
5 Menurut keterangan carik Sukorejo yakni Pak Sholikin, jumlah pegawai dan juga buruh tani yang dimiliki Kaji Zen tidak diketahui secara pasti karena tidak ada penghitungan yang dilakukan sebulumnya oleh keluarga Kaji Zen. Buruh tani dan pegawai yang bekerja untuk mengelola sawah dan depo penggilingan padi, hanya bekerja pada saat masa panen tiba selebihnya mereka mencari pekerjaan lainnya seperti menjadi pemulung. Para buruh tani dan pegawai yang bekerja di Kaji Zen, memiliki sistem pembayaran upah yang berbeda dengan tuan tanah lainnya baik di Sukorejo maupun didesa
}

"Lak Pak Zen sing nyalonne yo ra enek musuhe, Mbak wong iku bose, la Abdi iku opo yo iso dadi lak ra onok bose kui. La aku iki kan burue Kaji Zen mbak yo'an, kadang kon nyopiri nyonyae belonjo. Apik lo Mbak Kaji Zen i ngerti wong cilik, la karyawane Pak Zen iku meh sak deso iki, Mbak akeh" (Wawancara, 29 Juni 2013). Kalau Pak Zen yang nyalon dapat dipastikan ndak ada lawannya karena dialah bosnya, nah Abdi itu apa bisa jadi lurah kalau ndak ada bosnya. Saya ini kan buruhnya Kaji Zen juga, Mbak. Baik lo, Mbak Kaji Zen itu, pengertian sama rakyat kecil, karyawannya pak Kaji Zen itu hampir sedesa banyak, Mbak.

Beberapa warga mengatakan bahwa relasi yang dibangun Kaji Zen dan Lurah Abdi sebenarnya berlatar belakang fanatisme Islam. Hal tersebut terjadi karena kebiasaan Lurah Zen yang selalu menjadi donator dalam setiap pembangunan mushola di Desa Sukorejo. Peristiwa ini diceritakan oleh Pak Misran yang menjelaskan bahwa " Kaji Zen iku wong apik nduk, ger enek pembangunan mushola ora tau absent. Mbuh watu, krikil, semen opo boto mesti sing nyukupi kaji Zen" Kaji Zen itu orang baik, Nduk, tiap ada pembangunan mushola ora tau absen. Entah Batu, krikil, semen atau Batu bata pasti yang memenuhi Kaji Zen (Wawancara, 1 Juli 2013).

Adanya pemanfaatan kekuatan suara dari moral dan resiprositas antara klien-klien

tetangga. Sistem pembayaran upah diberikan bersamaan dengan bonus beberapa kilo beras.

${ }^{6}$ Hal tersebut sama contohnya dengan penelitian Scott pada petani di Filipina, dimana pola persekutuan diantara perseorangan pada umumnya ditafsirkan dalam rangka resiprositas atau faham 'setiap jasa diterima, di minta atau tidak dibalas' Dimana rasa malu (hiya) dan rasa hutang dudi (utang na loob) merupakan daya pergerakannya. Lihat di buku Scott, J.C. (1981). Moral Ekonomi Petani. Jakarta: LP3ES. hlm.256. 
yang dimiliki oleh Kaji Zen untuk Lurah Abdi, dilatarbelakangi oleh kedekatan Lurah Abdi dengan Kaji Zen dalam Satu organisasi Islam RECO (Remaja Sukorejo) ${ }^{7}$. Dari organisasi ini kemudian Lurah Abdi terlibat Utang Piutang dengan Kaji Zen. Menurut keterangan dari beberapa buruh Kaji Zen, Lurah Abdi saat itu meminjam dana sebesar seratus juta dengan Jaminan Bengkok Lurah seluas 3 Hektar. Dari transaksi tersebut akhirnya Kaji Zen Mengerahkan kekuatan Kliennya untuk memenangkan Lurah Abdi kembali lewat dukungan suara. Hal ini juga dijelaskan oleh calon Lurah lainya pada pemilihan 2007. Pak Widi (38) yang menjelaskan :

"Disini itu karakteristiknya mbak seumpama ada si A ini punya sawah, punya kebun tebu otomatis butuh banyak sekali pegawai secara otamatis punya banyak orang. [...]Disini itu ada orang yang paling disegani, Mbak namanya Kaji Zen anaknya Kaji Aziz. Beliau itu wakil keluarga, Mbak, apalagi Kaji Zen ini orangnya dermawan kalau warga butuh apa-apa itu beliau ada. Kalau kaji Zen nyalon ya ndak ada berani nglawan tapi kanyaknya ndak wong ngurusi tanahe wae sak munu mbane. Nah kemarin itu yang Pak Abdi itu di dukung sama Kaji Zen"(Wawancara, 27 Juni 2013).

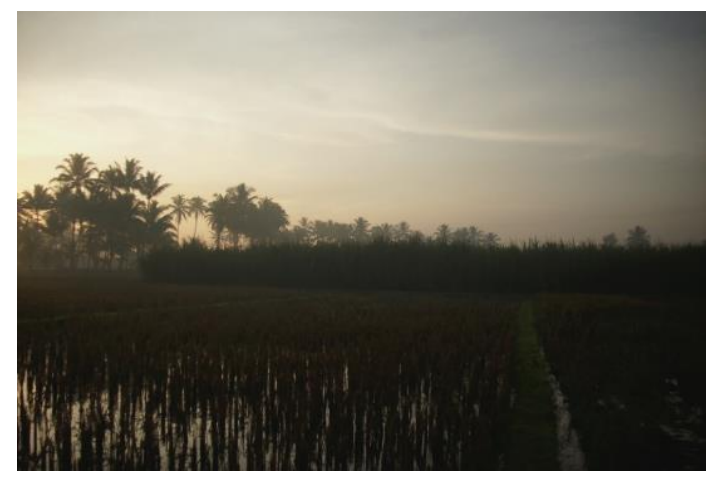

Foto sawah tebu seluas 3 hektar yang merupakan bengkok lurah (Sumber : Dokumen Pribadi)

\footnotetext{
7 Keterlibatan Kaji dalam organisasi masyarakat baru dimulai paca abahnya atau Kaji Azis

Penjelasan lainnya juga di jelaskan oleh Pak Sami'i (62 th), beliau menguatkan argumentasi dari pola perpolitikan Lurah Abdi yang sebelumnya diterangkan oleh Pak Widi. Pak Sami'i mengatakan :

" Ngene mbak abdi kui pancen wong pendalungan, la lak jenenge bos bolone lak akeh a dadi abdi iku di kenalne lewat bolo nyalur bolo neh akhire dadi akrab. La sing ngolah tebune iku lak Boz Zen to, penjanjianne kan Abdi utang nek gone Bos Zen lunasan ne sawah tebu jatah lurah kui. Asline aku ra pati srek karo abdi, aku biyen dukung Widi, tapi mergo perintahe bos milih Abdi yo piye meneh akhire menggok lak ra manut bose yo dadi masalah. Akeh- akeh iku ngono, Mbak, podo miker weteng dari pada pilihane dewe, mergo iso menang iku yo soko sokongange karyawane Pak Zen ki sing akeh-akeh dadi buruh nek sawah ceritane ngunu."(Wawancara, 29 Juni 2013).

Jadi gini, Mbak Abdi itu memang orang Pendalungan, nah yang namanya bos itukan koneksinya banyak, jadi Abdi itu dikenalkan lewat teman ke teman akhirnya jadi akrab. Nah yang mengelola tebu jatah lurah itu kan Bos Zen to, perjanjiannya kan Abdi hutang ke Bos Zen pembayarannya Sawah tebu jatah lurah. Sebenarnya saya ndak terlalu mendukung Abdi, saya dulu mendukung Widi tapi karena perintah bos jadi milih Abdi, mau gimana lagi, Mbak, orangorang lebih memikirkan urusan perut dibanding pilihan suara hati mereka. Dia bisa menang itu karena dukungan yang diberikan Pak Zen itu banyak dan mayoritas mereka jadi buruh sawah, gitu ceritanya.

Perjajian penyewaan sawah yang dilakukan oleh Kaji Zen dan Lurah Abdi adalah selama lima tahun. Sedangkan satu tahun diakhir masa jabatan sawah tersebut dikelola oleh Lurah Abdi sendiri. Total

Meninggal. Sebelumnya Kaji Zen tidak pernah terlihat aktif di organisasi Desa Sukorejo. 
hutang 100 juta sebenarnya bukan total yang sangat besar untuk ukuran modal pencalonan lurah di Desa Sukorejo. Dalam pencalonan lurah Sukorejo modal yang dibutuhkan berkisar 300 juta. Modal kampanye tersebut digunakan untuk memperkuat dukungan di masyarakat. Akan tetapi, strategi yang dijalankan oleh lurah Abdi menggandeng Kaji Zen sebagai Mitra politiknya mampu memangkas pengeluaran kampaye hingga 200 juta $^{8}$.

Lurah Abdi sebenarnya merupakan wirausahawan yang cukup terpandang di Desa Sukorejo. Lurah Abdi memiliki toko material bangunan di Desa Sukorejo. Aksesnya yang luas membuat Lurah Abdi memiliki jaringan politik yang cukup kuat terutama dikalangan kaum ekonomi kelas atas di Desa Sukorejo Gondanglegi Malang. Sehingga, alur inilah yang memudahkan Lurah Abdi mendapat suara terbanyak dari dua calon lainnya.

\section{Situasi Pemilihan Lurah 2007}

Sepanjang jejak rekam perpolitikan di Desa Sukorejo, desa tersebut memiliki budaya pemilihan umum yang cukup unik. Selain besarnya modal yang diperuntukan dalam pencalonan Lurah dan Jaminan tanah bengkok lurah yang cukup luas, tradisi carok juga muncul disana. Kebudayaan yang cenderung mengarah ke Pendalungan akibat banyaknya warga Madura yang bermigrasi ke Sukorejo, membuat akulturasi budaya tidak dapat dihindari. Pada pemilihan umum sebelumnya atau tepatnya pada masa pencalonan Lurah Purdopo tahun 2002, terjadi bentrok yang berujung pada terjadinya tradisi kekerasan carok, namun saat itu dapat diantisipasi oleh

\footnotetext{
${ }^{8}$ Calon lain seperti Pak Widi Aji menghabiskan modal pencalonan lurah sebanyak 300 juta. Hal tersebut mengakibatkan kerugian yang cukup besar hingga membutuhkan waktu pemulihan ekonomi selama enam tahun. Membaca taktik politik yang dijalankan Lurah Abdi, Pak Widi juga menggunakan trik tersebut dalam pencalonan sebagai lurah pada masa pemilihan 2012. Terlebih ada ikatan keluarga yang akan terjalin dengan keluarga Kaji Zen. Hal ini
}

tuan tanah Desa Sukorejo atau dalam hal ini adalah Kaji Zen. Peristiwa tersebut diceritakan oleh mantan calon lurah 2007 yakni Pak Widi. Pak Widi menjelaskan, pada saat pemilihan umum dengan calon Pak Purdopo atmosfir perpolitikan desa memanas. Hal tersebut tidak hanya terjadi saat pemilihan umum 2002 saja melainkan juga pada pemilihan umum tahun 2012. Pak Widi menerangkan :

"Dulu, Mbak, pas waktune Pak
Purdopo pernah ada yang hampir
carok, kan disini itu ada masyarakat
Maduranya juga, Mbak jadi ya
tegang-tegangan kalau pas pemilihan
umum. Kalau ndak seneng gitu pasti
bentrok, pas saya nyalon dulu juga
tegang-tegangan, Mbak. Sebulan
sebelum pemilihan itu udah panas
hawane"(Wawancara, 3 Juli 2013).

Tata cara pemilihan lurah atau pencoblosan lurah tidak menggunakan lembar suara bergambar foto melainkan dengan menggunakan kertas bergambar buah. Hal ini dilakukan untuk melestarikan tradisi dan mengurangi konflik antara calon yang satu dengan lainnya. Saat pemilu 2007 ketegangan terjadi, namun dapat diminimalisir akibat adanya relasi patronklien yang turut dimainkan disana. Pada Pertarungan perpolitikan tahun 2007 konfik lebih terlihat lewat harmonisasi sosial masyarakat Sukorejo yang terganggu. Hal ini dipraktekan lewat tidak saling menyapanya antar tetangga.

Pada tahun pemilihan 2007 terdapat tiga calon kepala desa yang akan bertarung demi mendapatkan kursi jabatan 2007-2013. Calon tersebut terdiri dari Purdopo, Abdi

diutarakan langsung oleh Pak Widi sebagai berikut : "ini sebentar algi kan pemilihan mbak biasannya jarak setahun itu suasananya sudah panas mbak antar tetangga itu sudah tidak saling menyapa, tapi alhamdulilah kemarin itu teman-teman yang akan nyalon itu sudah saya dan teman-teman termasuk juga Pak Zen ikut untuk memberi pesan jangan bilang-bilang dulu nanti saja kalau sudah dekat"(Wawancara, 27 Juni 2013). 
dan Widiaji. Saat itu, konsentrasi suara terfokus pada dua calon yaitu Widi dan Abdi. Widi mendapat banyak perolehan suara. Mereka yang memilih Widi saat itu merupakan warga Sukorejo yang tidak termasuk klien dari Kaji Zen. Hal tersebut juga mencakup tiga suara yang datang dari pamong desa. Perolehan suara yang di dapat Pak Widi saat itu hampir menyamai Lurah Abdi. Sayangnya perolehan suara lurah Abdi lebih banyak 16 suara dari pada Pak Widi. Dari total pemilih 2724 Jiwa, Lurah Abdi mendapat perolehan suara sebanyak 1.370, sedangkan Pak Widi 1354 suara dan Pak Purdopo sebanyak 0 suara ${ }^{9}$. Dari perolehan tersebut Lurah Abdi unggul dan menjabat kembali sebagai Lurah untuk periode 2007-2013.

Motif politik dengan prinsip moral dan resiprositas yang dijalankan oleh Lurah Abdi tidak berhenti begitu saja. Setelah dirinya terpilih menjadi Lurah di periode yang kedua, Lurah Abdi memecat tiga pamong Kelurahan. Permasalahan tersebut terjadi akibat ketika pamong tersebut menolak menyumbangkan suaranya untuk Abdi pada pemilihan kepala desa tahun 2007. Tiga pamong itu adalah Mahmudi, Marsio dan Yamudi. Keterangan pencopotan tiga pamong tersebut di jelaskan oleh Pak Misran sebagai berikut “ ancene enek telu sing di copot pas abdi njabat sing kaping loro iki, enek telu Mahmudi, Marsio dan Yamudi gara-gara ne milih widi pas kui" memang ada tiga orang yang di pecat saat Abdi menjabat untuk kedua kalinya, tiga orang tersebut adalah Mahmudi, Marsio dan Yamudi garagara memilih Widi saat itu (Wawancara, 1 Juli 2013).

Perombakan susunan pamong juga ditegaskan oleh Mbah Sirat penjaga jembatan Sukorejo-Kepanjen. Salah satu keponakan Mbah Sirat merupakan anggota pamong yang dicopot jabatannya.

\footnotetext{
${ }^{9}$ Informasi ini didapat dari data pemilihan desa yang diinformasikan secara lisan oleh Carik desa yaitu Pak Sholikin.
}

Mengenai perang pamong yang diberhentikan dari jabatnnya adalah bagian keuangan dan dua pesuruh lurah. Mbah Sirat menjelaskan :

" Enek sing di copot salah sijine keponakanku dewe jenenge yamudi, kabehen telu sing di copot Yamudi bagian duit, Marsio pesuruh karo Mahmudi. Kuwi dicopote gara-gara ora milih pak abdi dadi lurah neh kanggo sing kaping loro tapi milih wong liyo" (Wawancara, 2 Juni 2013 ) Ada yang diganti salah satunya ponakan saya namanya Yamudi, semuanya ada tiga yang dipecat Yamudi bagian keuangan, Marsio pesuru dan Mahmudi. Dicopot karena tidak memilih Pak Abdi untuk jadi lurah yang kedua kalinya tapi memilih orang lain.

Pola politik yang dibangun berdasarkan prinsip moral dan resiprositas dalam bentuk patron-klien sebenarnya tidak hanya terjadi pada proses pra-pemilu. patron-klien juga diperankan oleh Lurah Abdi terhadap para bawahannya. Dalam persoalan pemecatan tiga pamong yang tidak memilihnya dalam pemilihan tahun 2007 terjadi tidak harmonisan atau kekacauan dalam konsep patron-klien di bidang politik desa. Hal ini didasari pada sifat keterpihakan sebagai satu kewajiban moral atas bawahan kepada atasan. Pengaruh kebudayaan kaum petani memperlihatkan konsep patron-klien tidak hanya bekerja pada ranah ekonomi saja, namun juga terbawa dalam Bagian kebudayaan yang lain seperti pada pola politik yang diperankan Lurah Abdi.

\section{Relasi Kapital Tuan Tanah, Klien dan Lurah}

Pola relasi yang terbentuk dari efek adanya budaya subsisten sebenarnya muncul lewat ranah budaya kapital yang dibangun dikalangan petani. Mereka, para buruh tani 
dan petani kecil yang berelasi dengan Kaji Zen secara langsung berhubungan dengan sistem produksi dibawah Kapital Kaji Zen. Sehingga relasi yang terjadi adalah buruh menjadi unsur utama dalam proses produksi padi. Pola ini juga dibahas oleh Marx dalam buku Brewer (2016:107) yang menjelaskan bahwa :

“produk kapita di bawah proses yang sinambung, proses yang reproduktif, tidak hanya menghasilkan komoditi nilai dan nilai lebih, tetapi juga memproduksi hubungan-hubungan kapitalis. Di satu sisi klas kapitalis, di sisi lain pekerja upahan"

Tenaga yang digunakan untuk memproduksi padi kemudian digantikan lewat upah dan jasa subsisten di luar upah. Komponen di luar upah inilah yang kemudian mengesahkan secara moral timbulnya hubungan resiprositas patron dan klien. Relasi patron-klien yang tercipta antara Kaji Zen dengan tenaga kerjanya kemudian membentuk suatu modal khusus. Modal khusus tersebut adalah akumulasi kewajiban moral yang harus dibayar bukan dengan material tetapi dalam bentuk tindakan sosial. Wujud tindakan sosial sebenarnya tidak terlalu jelas dan fleksibel. Fleksibilitas inilah yang digunakan dalam memenuhi suara yang dibutuhkan pada pemilihan Lurah Abdi.

Aspek lain dari terciptanya hubungan antara Kaji Zen dan Lurah Abdi sebenarnya dinaungi oleh prinsip ke Islaman yang sama. Hal ini tentunya dibuktikan lewat adanya wadah RECO (Remaja Sukorejo). Dari sini ikatan komunitas memaksa lahirnya solodaritas antar anggota, sehingga hal ini diperkuat adanya pertukaran kapital antara tuan tanah dan Lurah dalam bentuk Tanah bengkok yang digadai dengan uang 100 juta. Resiprositas sebanding ini tidak hanya menukarkan uang dengan tanah saja,

\footnotetext{
${ }^{10}$ Pemosisian tanah dikalangan masyarakat Sukorejo sama posisinya dengan apa yang dijabarkan oleh Mulyanto ,dkk (2009: 137). Mulyanto menjabarkan
}

melainkan akumulasi dari uang dan suara dengan tiga hektar tanah bengkok tebu.

Dalam pembahasan patronase yang tercipta pada gaya perpolitikan Lurah Abdi tidak hanya menitikberatkan relasi antara lurah dan tuan tanah melainkan juga lurah dan pamong desa. Relasi lurah dan pamong desa juga memiliki tipikal patron-klien yang sama dimana yang dipertukarkan adalah antara relasi atasan dan bawahan. Dalam kasus pemecatan tiga pamong pasca memilihan lurah periode 2007-2013, terlihat bahwa secara struktural, kedudukan atau posisi pamong selalu bergantung pada kebijakan Lurah. Hal tersebut diperkuat oleh adanya pemberian hak guna lahan bengkok atau tanah khas desa untuk para pamong ${ }^{10}$. Pemberian hak guna lahan inilah yang kemudian secara tidak langsung menciptakan relasi patron-klien yang tidak disadari. Secara sederhana gambaran relasi patron-klien yang melingkupi gaya perpolitikan Lurah Abdi dapat dilihat sebagai berikut:

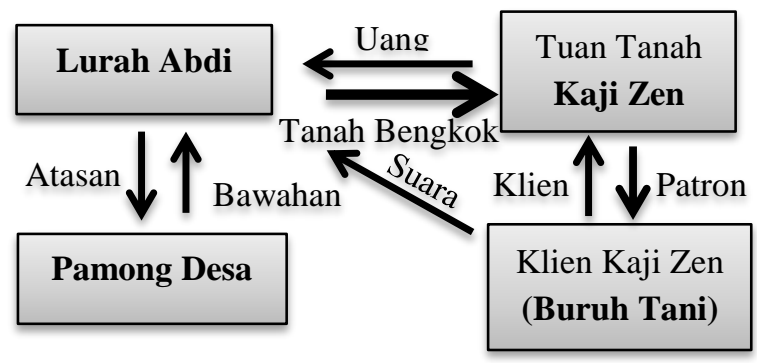

Gambar 3. Bagan Relasi Patro-Klien Lurah Abdi

Perpolitikan yang dijalankan Lurah Abdi secara umum mengaitkan relasi Patronklien yang cukup luas. Adanya ikatan piutang dengan Kaji Zen melibatkan relasi patron-klien yang dimiliki Kaji Zen. Hal ini kemudian disalurkan dalam bentuk suara untuk lurah Abdi. Bentuk dukungan suara dari para Buruh Kaji Zen, diposisikan sebagai kewajiban moral yang timbul

bahwa tanah, terutama tanah garapan, dalam masyarakat Kidulgunung dan Gunungsari dianggap sebagai pengaji bisa menjadi tempat untuk orangorang lain mengambil manfaat untuk kehidupannya. 
secara otomatis dari ikatan Patron-klien yang dibangun sebelumnya. Sedangkan, relasi patron-klien juga diposisikan dalam kuasa kepemimpinan sebagai lurah sebelumnya oleh Lurah Abdi. Ikatan kuasa antara bawahan dan atasan harusnya terjalin sebagaimana moral dan reprositas yang ada pada konsep Patron-Klien. Ketika kewajiban moral dan resiprositas tersebut tidak terpenuhi maka akan timbul sanksi sosial yang salah satunya dipraktekan dalam kasus pemecatan tiga Pamong. Dampak dari terputusnya rantai struktural antara tiga pamong tersebut juga diikuti dengan terputusnya hak guna tanah bengkok desa yang di miliki sebelumnya.

\section{Simpulan}

Kekuatan kuasa sebenarnya menciptakan suatu sinkronisasi atas pengaturan wewenang lintas kelas. Hal tersebut terjadi dalam bentuk-bentuk yang bervariasi. Tentunya bentuk tersebut dipengaruhi oleh kebudayaan yang berkembang di sana. Di Desa Sukorejo hal ini diwujudkan dalam bentuk relasi politik yang kental dengan budaya subsisten kaum tani, dimana kuasa tuan tanah menjadi suatu kunci pemulusan hajat atau niat yang diinginkan. Teori Galtung dalam Anshoriy (2008) yang mengemukakan bahwa kekuasaan dapat diperoleh jika memang kekuasaan itu mutlak ada, dapat dilihat bagaimana relasi antara tuan tanah dan lurah terjalin.

Galtung juga menambahkan bahwa kekuasan juga dapat diperoleh dengan sebuah kekayaan dan kekuasaan diperoleh karena adanya posisi struktural. Hal tersebut dibuktikan dengan adanya ikatan resiprositas antara Lurah dengan pamongnya. Secara struktural Lurah memiliki kuasa lebih tinggi sehingga pengambilan keputusan bisa didasarkan secara objektif maupun subjektif. Pengambilan keputusan akibat tidak memberikan suara dengan sanksi di pecat merupakan pengambilan keputusan secara subjektif dengan latar belakang budaya yang ada di Desa Sukorejo. Maka relasi sosial Patron-Klien yang dipraktekan dalam bentuk relasi ataupun struktur yang digambarkan oleh Scott (1981) merupakan bentuk dari kuasa dari kelas atas untuk kelas bawah. Hal ini juga diperkuat oleh pandangan Radcliffe Brown dalam buku Koentjoroningrat (2007) yang menjelaskan Suatu struktur sosial merupakan total dari jaringan hubungan antara individuindividu, atau lebih baik person-person dan kelompok-kelompok person. Dimensinya ada dua, yaitu: hubungan diadik, artinya antarapihak (yaitu person atau kelompok) kesatuan dengan pihak kedua, tetapi juga diferensial, antara satu pihak dengan beberapa pihak yang berbeda-beda, atau sebaliknya (Koentjoroningrat, 2007).

\section{Penutup}

Tulisan ini ditulis berdasarkan catatan penelitian tugas kuliah yang dilakukan pada 2013. Mengingat penelitian ini menggunakan metode Etnografi tentunya peneliti membutuhkan tempat tinggal di Desa Sukorejo. Selayaknya ucapan terima kasih saya ucapkan untuk para informan yang telah ikut berperan memberi informasi dan data yang dibutuhkan dalam pembahasan topik tulisan ini. Ucapan terima kasih yang pertama ditujukan untuk segenap jajaran Perangkat Desa Sukorejo, utamanya kepada Miftakhul Abdi selaku pemberi izin penelitian ini. Selanjutnya Ucapan terima kasih ditujukan kepada Pak Solikhin, Pak Widiaji, Pak Purdopo, Pak Ramin, Pak Sami'i dan Mbah Sirat yang telah meluangkan waktunya untuk di wawancarai. Ucapan terima kasih saya berikan kepada Keluarga Bapak Misran yang telah rela menjadi induk semang saya selama menjalankan penelitian. Selain itu, saya ucapkan terimaksih yang sebesarbesarnya kepada jajaran Dosen Antropologi yang telah membimbing jalanannya penelitian ini selama dilapangan. 


\section{Daftar Pustaka}

Anshoriy, H. N. (2008). Dekonstruksi Kekuasaan. Yogyakarta: LKIS.

Brewer, A. (2016). Kajian Kritis Das Kapital Karl Marx. Yogyakarta: Narasi.

Dede Mulyanto, d. (2009). Kapitalisasi Dalam Penghidupan Perdesaan. Bandung: Yayasan AKATIGA.

Fettersman, D. M. (2010). Etnograpy Step- by-Step. Washington DC: Sage pubictions.

Halili. (2009). Praktik Politik Uang dalam Pemilihan Kepala Desa. Jurnal Humaniora (Lemlit UNY), Volume 14 nomor 2, 99-112.

Koentjaraningrat. (2007). Sejarah Antropologi I. Jakarta: UI Press.

Koentjoroningrat. (1980). Sejarah Teori Antropologi. Jakarta: UI-Press.

Mauss, M. (2002). The Gift : The Form And Reason for Axchange in Archaic Societies. London: Routledge Classics.

Rohmawati, A. (2005). Dinamika Politik Pedesaan dalam Pemilihan Kepala Desa Masin Kabupaten Batang Provinsi Jawa Tengah. Jurnal Ilmu Politik dan komunikasi Unikom.

Scott, J. C. (1981). Moral Ekonomi Petani . Jakarta: LP3ES.

Simatupang, L. (2010). Pagelaran : Sebuah Mozaik Penelitian Seni Budaya. Yogyakarta: Jalasutra.

Tauchid, M. (2009). Masalah Agraria Sebagai Masalah Penghidupandan Kemakmuran Rakyat Indonesia. Yogyakarta: STPN press.

Tobing, A. A. (2009). Eksistensi Tanah Bengkok Setelah Perubahannya Pemerintahan Desa Menjadi Kelurahan di Kota Ssalatiga. Semarang: Universitas Diponegoro. 